\title{
Path Analysis on the Influence of Educational Level, Stages of Cancer, Social Support, and Coping Strategy toward the Quality of Life of Breast Cancer Patients in Dr. Moewardi Hospital, Surakarta
}

\author{
Sri Nuryati'), Ambar Mudigdo²), Bhisma Murti') \\ ${ }^{1)}$ Masters Program in Public Health, Sebelas Maret University \\ 2)Faculty of Medicine, Sebelas Maret University
}

\begin{abstract}
Background: Breast cancer develops into main health problem for women globally. Patients of breast cancer will endure transformation both physically as well as psychologically, it will give impact to the quality of life. The study aimed to analyze the influence of educational level, stages of cancer, social support, and coping strategy toward the quality of life of breast cancer patients.

Subjects and Method: The study employed mixed method with quantitative and qualitative approach. The study was conducted in Dr. Moewardi Hospital, Surakarta in August - October 2017. There were a total of 150 study subjects selected with stratified random sampling. Purposive sampling was used for qualitative study with 3 informants. The dependent variable was quality of life. The independent variables were educational level, stages of cancer, social support and coping strategy. Quantitative data collection was conducted by using questionnaires. Social support variable was measured by using Multidimensional scale of perceived social support (MSPSS) questionnaires, coping strategy variable was measured by brief COPE questionnaires and life quality variable was measured by WHOQOL BREF questionnaires. Data qualitative collection was by means in depth interview. Quantitative data was analyzed by using path analysis, qualitative data was analyzed by using interactive model Miles and Huberman.

Result: Quality of life was influenced by educational level $(b=8.69, \mathrm{SE}=1.84, \mathrm{p}<0.001)$, stages of cancer $(b=-6.41, \mathrm{SE}=2.94, \mathrm{p}=0.029)$, social support $(\mathrm{b}=1.03, \mathrm{SE}=0.34, \mathrm{p}=0.003)$, coping strategy $(b=2.07, S E=0.43, p<0.001)$. Coping strategy was influenced by educational level $(b=$ $0.97, \mathrm{SE}=0.34, \mathrm{p}=0.004)$ and social support $(\mathrm{b}=0.37, \mathrm{SE}=0.06, \mathrm{p}<0.001)$.

Conclusion: Quality of life of breast cancer patients is influenced by educational level, stages of cancer, social support, and coping strategy. Coping strategy was influenced by educational level and social support.
\end{abstract}

Key words: social support, coping strategy, quality of life, path analysis

\section{Correspondence:}

Sri Nuryati. Masters Program in Public Health, Sebelas Maret University, Jl. Ir. Sutami 36 A, Surakarta 57126, Central Java. Email: sri.nuryati1985@gmail.com. Mobile: +6282138283802.

BACKGROUND
Breast cancer develops into the main health
problems for women globally. The incidence
rates of breast cancer keeps on increasing
both in developed and developing countries.
Life style is one of the causes of the
increasing rate of breast cancer in
developing country (WHO, 2017).
Based on GLOBOCAN International
Agency for Research on Cancer (IARC) in
2012, breast cancer ranked fifth in cancer related deaths with a total of 521,907 deaths and among female population breast cancer was a type of cancer with the most new cases percentage that was $43.1 \%$ and it was the top cause of death with a total of $12.9 \%$. In 2012 the highest cancer incidence in Indonesia on women was breast cancer with 40.3 per 100,000 populations. The estimated death rate of breast cancer in Indonesia is 16.6 per 100,000 populations (IARC, 2017). In Dharmais Cancer Hospital Jakarta, breast 
Journal of Epidemiology and Public Health (2017), 2(3): 225-235

https://doi.org/10.26911/jepublichealth.2017.02.03.04

cancer ranked first in the last 10 years $u$ to 2016 and the incidence rate is increasing each year (Kemenkes, 2016). Yogyakarta Special Region in 2013 was a province with the highest prevalence of breast cancer with a total of $2.4 \%$ o. However based on the estimation the most breast cancer patients were in Central Java province with a total of 11,511 (Indonesia Health Ministri, 2015).

Breast cancer is a disease that influences all life aspects of the individual who suffers from the disease (Sastra, 2016). Diagnosis of breast cancer may interrupt physical, emotional, and spiritual health, as well as patient's personal relationship with the family (Esheshtawy et al, 2014). General symptoms that influence breast cancer patients are fatigue, insomnia, depression, cognitive difunction, reproductive symptoms (Pinto and Azambuja, 2011). Breast cancer medication will give impacts on physical, psychologival and social aspects (Fitri et al, 2017). Anxiety and fear will last in a long period of time and the death threat of the disease is troublesome for the patients and the condition will give impact on the quality of life of breast cancer patients (Prastiwi, 2012). Quality of life is one of the prognosis factors that influence breast cancer patients' survival and mortality (Rudiyo et al, 2012).

One of the purposes of health minister in cancer countermeasure is by putting cancer as the national health problem priority. One of the activities to support the commitment was improving the quality of life of cancer patients (Indonesian Health Ministry, 2015). The determinant factors of the quality of life on women with breast cancer include psychosocal factors with coping strategy, socio demography factor and medical factor (Mols in Li et al, 2015). According to Khalili et al (2013) cping strategy influences the quality of life of breast cancer patients. Age, clinical factors, social support and social economy status related to the quality of life of breast cancer patients (Høyer et al, 2011). Stage of cancer at the time of diagnosis is one of the factors influence the anxiety and depression condition (Helalah et al, 2014). According to Rab (2012) age and educational factor may influence the quality of life.

The quality of life of breast cancer patients is influenced by the individual's manner to understand the disease hence they understand how to maintain their health (Prastiwi, 2012). The higher the educational level the easier to receive information on care and treatment as well as adjust with the treatment given.

Unaccountable information circulating in society leads breast cancer patients to undergo inappropriate treatment and visit healthcare facilities after advanced stage thus it is too late for them to get treated, hence it will lower down the quality of life. More than $70 \%$ of cancer patients visit healthcare facilities with advanced stage of cancer (Indonesian Health Ministry, 2016). There are various reasons for the patients to come in condition of advanced stage, among others are fear of surgery, the perception that cancer is incurable and the high cost of cancer treatment (Sulistiowati et al, 2016).

The mission and vision of Indonesia Breast Cancer Foundation is Indonesia which is free from advanced stage breast cancer in 2030, among others by raising society's awareness toward breast cancer (Indonesian Health Ministry, 2016). Social support becomes an important factor for the quality of life of women diagnosed with breast cancer (Leung et al, 2014). Social support in the time of diagnosis may improve the quality of life (Hughes et al, 2014). Social support will help individual to perform adjustment or positive coping behavior that may improve the quality of life of breast cancer patients. According to 
Taylor (cit Prastiwi, 2012) support from the closest persons influences the recovery of cancer patients in term of reducing stress level and depression. Both psychological and material support from the surrounding environment may establish patients' personality to face the problems. Bigger social support is related to the higher quality of life post breast cancer diagnosis (Kroenke et al, 2013). Patients of breast cancer who are able to face the condition endured will have better quality of life, and negative responses of a cancer patient will generate negative quality of life also (Prastiwi, 2012).

The quality of life of breast cancer patients among others is determined by how the individual size up the disease, hence the patients may able to manage the anxiety they endure. Anxiety management can be conducted by self adjustment. In psychology, self adjustment is known as coping strategy. By improving psychological adjustment with cancer and able to improve quality of life (Hajian et al, 2017).

\section{SUBJECTS AND METHOD}

This was a mixed method study with quantitative and qualitative approach. The quantitative study used cross sectional design, whereas phenomenology approach was used for qualitative study. Qualitative data supplemented qualitative data. The study was conducted at Dr. Moewardi Hospital, Surakarta from August to October 2017.

Table 1. The result of reliability test on questionnaires

\begin{tabular}{lcc}
\multicolumn{1}{c}{ Variable } & Item Total Correlation (r) & Cronbach's Alpha \\
\hline Social support & $\geq 0.34$ & 0.82 \\
Coping strategy & $\geq 0.24$ & 0.87 \\
Quality of life & $\geq 0.21$ & 0.90 \\
\hline
\end{tabular}

\section{RESULT}

Characteristics dimension of study subjects observed from age, educational level, occupation, family income, marital status.
Population of the study was patients of breast cancer at Dr. Moewardi Hospital. The sample was 150 study subjects selected by using stratified random sampling. There were 3 informants who were selected for qualitative analysis by using purposive sampling.

The dependent variable was quality of life. Independent variables were educational level, stages of cancer, social support and coping strategy.

Quantitative data collection used questionnaires. Social support variable was measured by using multidimensional scale of perceived social support (MSPSS) questionnaires, coping strategy variable was measured by brief COPE questionnaires, and quality of life variable was measured by WHOQOL BREF questionnaires. Qualitative data collection used in depth interview. The quantitative data was analyzed by using path analysis. The qualitative data was analyzed by using Miles and Huberman interactive model.

Based on item-total correlation reliability test it was found that on social support, coping strategy and quality of life variable measuring, the value of $r$ counting $\geq 0.20$, and Cronbach Alpha $\geq 0.60$, therefore all question items were stated as reliable. The result of reliability test on questionnaires could be seen in Table 1 .
The disease characteristics were seen from stages of cancer and duration of disease. Table 2 showed that out of 150 study subjects $78 \%$ aged $\geq 45$ years old, $34.7 \%$ 
Journal of Epidemiology and Public Health (2017), 2(3): 225-235

https://doi.org/10.26911/jepublichealth.2017.02.03.04

were elementary school graduates, $66.7 \%$ whose income $\geq 1$ million rupiah, $49.3 \%$ were housewives, and $83 \%$ were married, most of them belonged to stage $3(45 \cdot 3 \%)$, and $78.7 \%$ had suffered for more than a year.

Table 2. Characteristics of study subjects and the disease

\begin{tabular}{|c|c|c|c|}
\hline Characteristics & Criteria & $\mathbf{n}$ & $\%$ \\
\hline \multirow[t]{2}{*}{ Age } & $<45$ year & 33 & 22 \\
\hline & $\geq 45$ year & 117 & 78 \\
\hline \multirow[t]{5}{*}{ Education } & Never went to school & 23 & $15 \cdot 3$ \\
\hline & Elementary & 52 & 34.7 \\
\hline & Junior High School & 25 & 16.7 \\
\hline & High School & 30 & 20 \\
\hline & Associate's/ Bachelor's Degree & 20 & 13.3 \\
\hline \multirow[t]{2}{*}{ Family income } & $<\operatorname{Rp} 1,000,000$ & 50 & 33.3 \\
\hline & $\geq \operatorname{Rp~1,000,000}$ & 100 & 66.7 \\
\hline \multirow[t]{6}{*}{ Occupation } & Housewives & 74 & 49.3 \\
\hline & Farmer & 35 & $23 \cdot 3$ \\
\hline & Self -employed & 13 & 8.7 \\
\hline & Private employee & 6 & 4 \\
\hline & Civil Servant & 9 & 6 \\
\hline & Others & 13 & 8.7 \\
\hline \multirow[t]{3}{*}{ Marital status } & Married & 125 & 83.3 \\
\hline & Divorced/ Widowed & 23 & $15 \cdot 3$ \\
\hline & Not married yet & 2 & 1.3 \\
\hline \multirow[t]{4}{*}{ Stages of cancer } & 1 (one) & 8 & $5 \cdot 3$ \\
\hline & 2 (two) & 61 & 40.7 \\
\hline & 3 (three) & 68 & $45 \cdot 3$ \\
\hline & 4 (four) & 13 & 8.7 \\
\hline \multirow[t]{2}{*}{ Duration of disease } & $<1$ year & 32 & 21.3 \\
\hline & $\geq 1$ year & 118 & 78.7 \\
\hline
\end{tabular}

The result of descriptive statistics on continuous data in the form of educational level, stages of cancer, social support, coping

\begin{tabular}{lccccc}
\multicolumn{6}{l}{ Table 3. Univariate analysis on variables of the study } \\
\hline \multicolumn{1}{r}{ Variables } & n & Min. & Max. & Mean & SD \\
\hline Educational level & 150 & 1 & 5 & 2.81 & 1.30 \\
Stages of cancer & 150 & 1 & 4 & 2.57 & 0.73 \\
Social support & 150 & 46 & 84 & 66.87 & 7.66 \\
Coping strategy & 150 & 61 & 89 & 74.83 & 6.02 \\
Quality of life & 150 & 160.27 & 332.14 & 236.83 & 36.21 \\
\hline
\end{tabular}

Table 3 showed that each variable had relatively small data variation. Mean represented the average value, whereas standard deviation (SD) represented how varied the data is. Small SD was an indication that the data is representative.

Table 4 showed that high educational level $(\mathrm{r}=0.55, \mathrm{p}<0.001)$, strong social strategy, and quality of life can be seen in Table 3 .

support $(r=0.52, p<0.001)$ and excellent coping strategy ( $\mathrm{r}=0.59, \mathrm{p}<0.001)$, had positive influence toward the quality of life of breast cancer patients and statistically significant, whereas stages of cancer $(r=-$ $0.12, p=0.137$ ) had negative effect toward the quality of life of breast cancer patients and statistically insignificant. 
Table 4. Bivariate correlation on the influence of educational level, stages of cancer, social support and coping strategy toward the quality of life of breast cancer patients

\begin{tabular}{lcc}
\hline Independent Variable & Bivariate Correlation(r) & p \\
\hline Educational level & 0.55 & $<0.001$ \\
Stages of cancer & -0.12 & 0.137 \\
Social support & 0.52 & $<0.001$ \\
Coping strategy & 0.59 & $<0.001$ \\
\hline
\end{tabular}

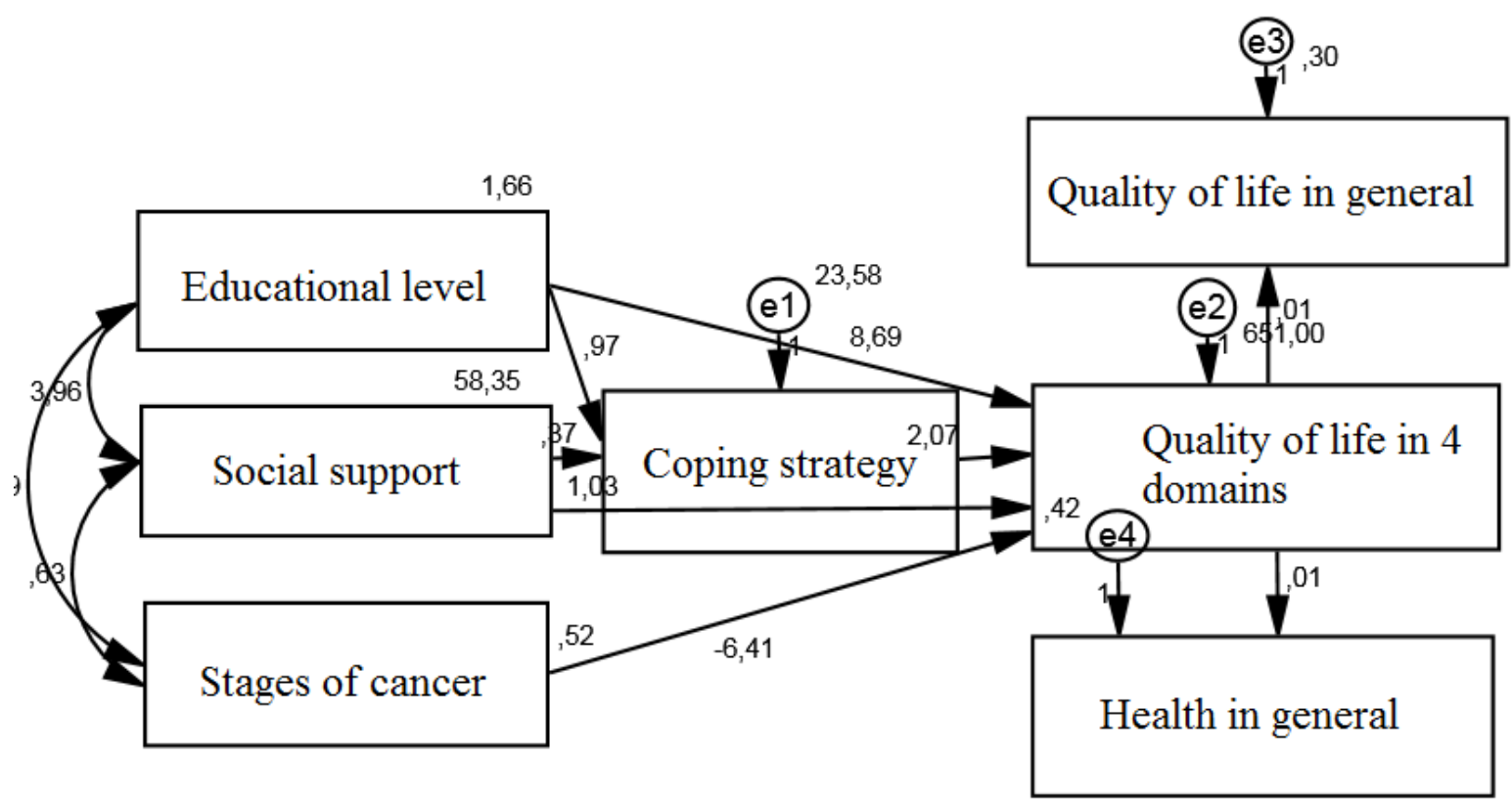

Picture 1. Structural model of path analysis

Picture 1 showed structural model after an estimation by using IBM SPSS AMOS 22, hence it found some values as it was presented in the image. The indicators that showed the model fit of path analysis as it was presented in Table 5 also indicated the occurrence of goodness of fit measure that it found CMIN fit index 13.69 with $\mathrm{p}=$ $0.188>0.05$; NFI $=0.95 \geq 0.90 ;$ CFI $0.99 \geq$ 0.95 ; RMSEA $=0.05 \leq 0.08$ which meant that the empirical model met the set criteria and stated as in accordance with the empirical data.

From Table 5 it was discovered that the quality of life was directly influenced by educational level, stages of cancer, social support and coping strategy.
Every unit increase of high educational level would increase the quality of life by 8.69 unit $(b=8.69 ; \mathrm{SE}=1.84 ; \mathrm{p}<0.001)$

Every unit increase of stages of cancer would decrease the quality of life by 6.41 unit $(b=-6.41 ; \mathrm{SE}=2.94 ; \mathrm{p}=0.029)$.

Every unit increase of excellent social support would increase the quality of life by 1.03 unit $(b=1.03 ; \mathrm{SE}=0.34 ; \mathrm{p}=0.003)$.

Every unit increase of strong coping strategy would increase the quality of life by 2.07 unit $(b=2.07 ; \mathrm{SE}=0.43 ; \mathrm{p}<0.001)$.

Every unit increase of 4 domains of good quality of life would increase the quality of life in general by 0.01 unit $(b=$ 0.01, SE<0.001; $\mathrm{p}<0.001$ )

Every unit increase of 4 domains of good quality of life would increase the 
Journal of Epidemiology and Public Health (2017), 2(3): 225-235

https://doi.org/10.26911/jepublichealth.2017.02.03.04

quality of life in general by 0.01 unit $(b=$ $0.01, \mathrm{SE}<0.001, \mathrm{p}<0.001$ )

Coping strategy was influenced by educational level and social support

Every unit increase of high educational strategy by 0.97 unit $(b=0.97, \mathrm{SE}=0.34, \mathrm{p}$ $=0.004$ ).

Every unit increase of strong social support would increase excellent coping strategy by 0.37 unit $(b=0.37, \mathrm{SE}=0.06, \mathrm{p}$ $<0.001)$.

level would increase excellent coping

Table 5. The result of path analysis on the influence of educational level, stages of cancer, social support and coping strategy toward the quality of life of breast cancer patients.

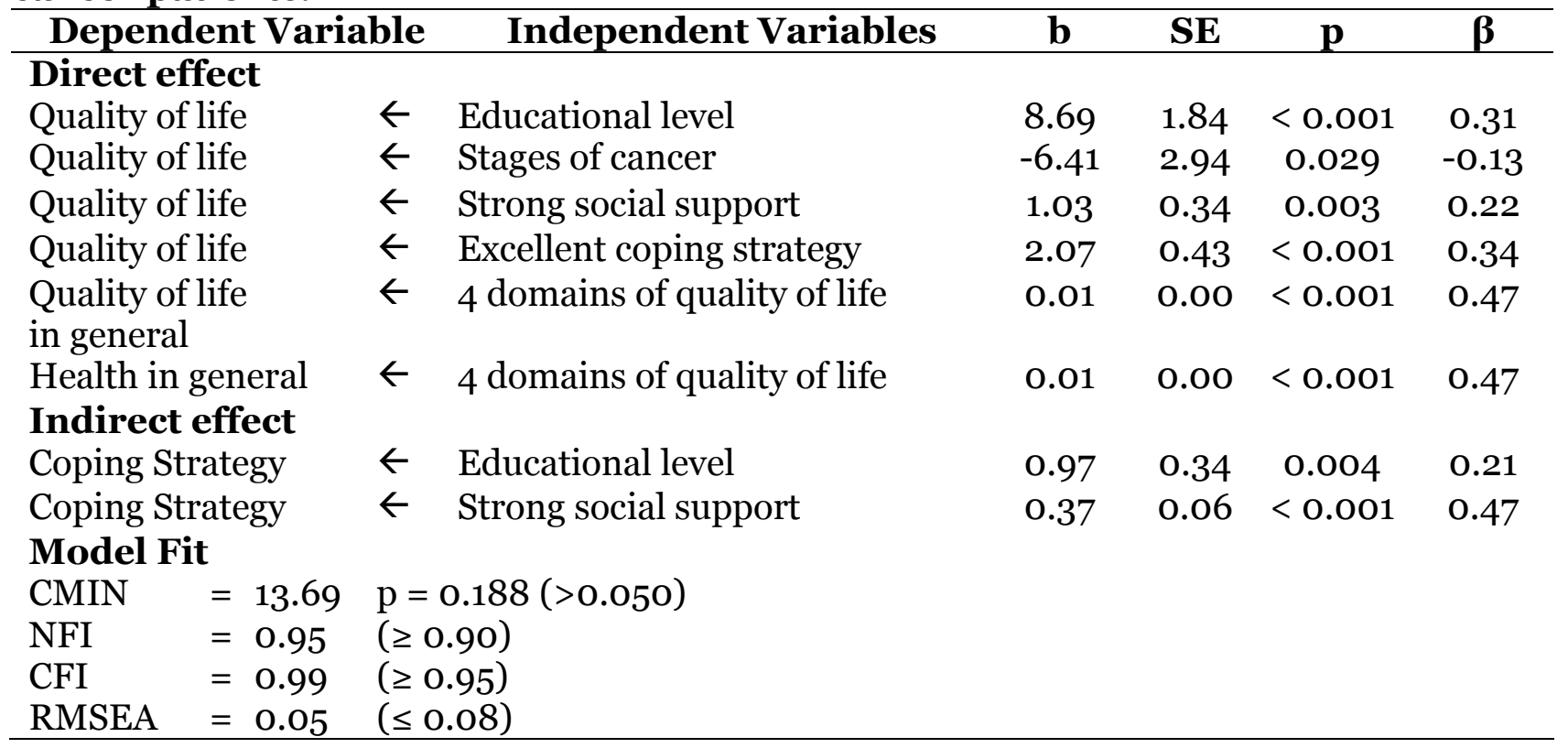

\section{DISCCUSION}

1. The influence of educational level toward the quality of life of breast cancer patients

There was a positive association between the quality of life of breast cancer patients and statistically significant.

It is in line with the result of a study conducted by Lusiatun et al (2016) that showed that breast cancer patients with high educational level will increase global health status 4 times bigger compare to patients with low educational level.

Educational level may improve one's quality of life. Educational level will influence one's mindset, the higher one's educational level is, the more anticipative they will be, therefore the disease treatment can be conducted immediately. Education is a factor for a person to determine an option for medication. One with high educational level can understand more on the disease and the treatment instruction. High educational level may influence the obtained information, patients may understand information better, having a good cognitive to accept, seeking for information on their treatment. The higher the educational level is, the easier to accept information on treatment and medication as well to adjust with the medication given.

2. The influence of stages of cancer toward the quality of life of breast cancer patients

There was negative association between stages of cancer with the quality of life of breast cancer patients and statistically significant.

In general, public awareness toward breast cancer in Indonesia is still relatively 
low. It can be seen from the fact that most women visit doctors with advanced stage of cancer (Kemenkes, 2016).

The course of cancer generally starts with in situ cancer or local cancer. In the stage usually there no symptoms occur however it is microscopically detected. The local cancer phase is generally quite long before it invades outside the organ. The initial symptoms of breast cancer are often unnoticed or sensed by patients therefore there are a lot of patients who get medical treatment in advanced stage of cancer. In advanced stage, cancer is difficult or incurable. The result of cancer treatment in early stage is better that in advanced stage. The earlier the cancer is found and treated, the better the prognosis or the expectancy of recovery (Rasjidi, 2010).

In the condition of advanced stage, cancer patients do not only endure physical problems but also psychological and spiritual disorder that influence their quality of life. Among stage four cancer patients declines occur in physical, social and spiritual health (Irawan, 2013).

In the condition, patients endure pain that needs integrated approaches from various disciplines so that patients have better quality of life. Palliative treatment helps cancer patients to live more conveniently hence they have better quality of life. Palliative program for cancer patiens $\mathrm{s}$ an integrated approach by palliative team to achieve patient's quality of life and the more dignified death as well as to give support for family in facing problems related to patients' condition by preventing and reducing suffering by means of early identification, thoroughly evaluation, also treatment for pain and other problems, physically, psychologically and spiritually (Kemenkes, 2015).

\section{The influence of social support toward the quality of life of breast cancer patients}

There was positive association between social support and breast cancer patients' quality of life and statistically significant.

The study is supported by a study conducted by Husni et al (2015) that stated that there is significant association between family support and breast cancer patients' quality of life. Family support is extremely needed in the process of recovery and will improve the general health status of family members who are sick.

Physical transformation undergo by breast cancer patients will influence the patients' self concept. A study conducted by Sastra (2016) found that 53,3\% of breast cancer patients have negative self concept. Patients with negative self concept will endure depression. Family has important role and influence in the establishment of self concept. A family that is able to give comfortable environment, love, attention and appreciation toward breast cancer patients so that able to improve good self concept. Self concept does not only develop from themselves but also develop in the interaction with society (Kamelia in Sastra, 2016).

Family support is a process happens during a life time. Family support is one of the stepping stones in facing a problem, family will give motivation. Cancer patients who obtain support from family and friend are able to overcome the disease well. Family support gives positive result toward patients' wellbeing and welfare. The occurrence of family support makes patients stronger in facing the disease (Sastra, 2016). According to Taylor in Siregar (2014) support from the closest persons is very important and influence the recovery of cancer patients in reducing stress level and depression. 
Journal of Epidemiology and Public Health (2017), 2(3): 225-235

https://doi.org/10.26911/jepublichealth.2017.02.03.04

Dominant aspect of the quality of life establishment among cancer patients is the psychological aspect including spirituality, social support and welfare. Love and comfort from social support will give motivation to recover and be tough in life. A study conducted by Endiyono and Herdiana (2016) stated that there is significant association between social support and quality of life of breast cancer patients. Social support is extremely needed in improving mental health, spirit of life and quality of life of breast cancer patients.

The result of the interview showed that social support obtained from family, closest persons, and friends really helps breast cancer patients in going through the disease: the statement can be seen from the following quotation:

"Well, everyone supports to get better soon and be strong, her older sister also (sobbing) sometimes she remembers her father, she wants him to be here, but how can it be? We always make phone conversations but still she wants her father's company.". (SH, result of interviewo2-112017).

"fine.. good.. we keep supporting, consoling, I have a daughter who is a nurse, in Jakrta... she was here for my surgery, and took care of me". (SL, result of interview 12-11-2017).

"Absolutely, the first one was my husband, the second one Bu RT. I went to bu RT first, told her that I had lumps on my breast. The motivation comes from my friends and from the material also... ". (YS, result of interview 02-11-2017).

Individuals who obtain high social support will be optimistic individuals and are more adjustable with the source of the stress. Social support influence one's adjustment toward cancer and therapy they undergo (Matthew in Endiyono and Herdiana, 2016). High level of satisfaction toward social support is related to better health outcome and lower psychological stress (Bloom et al in Endiyono and Herdiana, 2016). Psychological health of breast cancer patients should be cultivated by improving social support (Wang et al, 2014).

\section{The influence of coping strategy toward the quality of life of breast cancer patients}

There was positive association between coping strategy and breast cancer patients' quality of life and statistically significant.

Diagnosis of breast cancer may influence various aspects of life, harm physical, emotional and spiritual health and interpersonal relationship with family (Esheshtawy et al, 2014). Cancer diagnosis and treatment are considered as a stressful life experience, presenting great challenge for women. Breast cancer threaten the patients' self confidence and psychological state (Cordova et al in Silva et al, 2012). Breast cancer is a problem in women's life and raising some psychological problems such as anxiety, depression, fear of relapse, worry over their family and future therefore they need the appropriate intervention (Joulaee et al in Hajian et al, 2017).

According to Taylor (in Siregar and Rina, 2014) on women with breast cancer who undergo mastectomy, psychological symptoms will emerge, such as depression, stress, and anxiety. Chemotherapy treatment gives negative impact to psychological state of breast cancer patients who undergo it. The occurrence of disease that influence physical health is one of the aspects that determine the quality of life since the patients endure physical and psychological condition drawback. One of the forms of quality of life drawbacks is psychological dimension drawback. Effective strategy implementation may improve psychological adjustment toward cancer disease and able 
to improve quality of life (Hajian et al, 2017).

Coping can be defined as consistent cognitive transformation to manage external or internal pressure that is considered as the stress source. Coping strategy is used during breast cancer diagnosis for postsurgery psychological adjustment (Degner in Drageset et al, 2009). Coping strategy is used to regulate or transform the stress source (problem focused coping) and to regulate stress emotion (Emotion focused coping). Educational level influence the coping strategy of patients who are diagnosed with cancer (Zucca et al, 2010). Coping strategy may influence the result of treatment and the level of survival of women with breast cancer (Khalili et al, 2013). The result of a study conducted by Mardiana et al. (2013) showed that there is significant association between coping mechanism and the quality of life of cervical cancer. Coping strategy is extremely important to be used by individuals in solving problems, the effective coping will help individuals free from long stress.

An adaptive coping strategy and social support are the efforts for psychological adjustment by establishing positive perception hence may ease the suffering (Silva et al, 2012). An adaptive coping strategy is beneficial for cancer patients who undergo treatment and is able to generate better psychological state (Kvillemo and Branstrom, 2014).

Coping strategy employed by breast cancer patients is being more religious, they believe that God has chosen the circumstance for them and they should get through it (Esheshtawy et al, 2014). Belief in God's power leads patients to surrender, let go, and accept the fate God has given. According to Fitriani (in Endiyono and Herdiana, 2016) the effort to be more religious such as praying and always think positively, will leads to excellent quality of life. Based on the result of interview with the informants after breast cancer diagnosis they became more religious and accept the condition. The statement can be discovered from the quotation below:

"Well, I feel normal, I surrender myself to God. Now I think I will recover. I read that early stage of cancer can be healed. I also manage to recover, I become more religious, and read Bible, since I'm Christian.”

Belief in God is significantly related to the improving psychological welfare, reducing psychological pressure and worry over relapse (Schreiber, 2011)

Based on the result of the study, it can be concluded that quality of life is influenced by educational level, stages of cancer, social support and coping strategy.

\begin{tabular}{c}
\hline REFERENCE \\
\hline Drageset S, Lindstrøm TC, Underlid K \\
(2009). Coping with breast cancer: \\
between diagnosis and surgery. Jour- \\
nal of Advanced Nursing, 66(1): 149- \\
158. \\
Endiyono, Herdiana W (2016). Hubungan \\
Dukungan Spiritual Dan Dukungan \\
Sosial Dengan Kualitas Hidup Pasien \\
Kanker Payudara Di Rsud Prof. Dr. \\
Margono Soekarjo Purwokerto. \\
Jurnal Ilmiah Ilmu-ilmu Kesehatan, \\
14(2): 16-23 \\
Elsheshtawy EA, Elez WFA, Ashour HS, \\
Farouk O, Zaafarany MIEE (2014). \\
Coping Strategies in Egyptian Ladies \\
with Breast Cancer. Breast Cancer: \\
Basic and Clinical Research 8: 97-102. \\
SUR, Maneewat K, Sangchan H \\
(2017). Psychosocial Needs Among \\
Indonesian Women Diagnosed With \\
Breast Cancer. Journal of Nursing and \\
Health Care, 4(2): 67-72
\end{tabular}
(2009). Coping with breast cancer: (2009). Coping with breast cancer: between diagnosis and surgery. Journal of Advanced Nursing, 66(1): 149-

Dukungan Spiritual Dan Dukungan Sosial Dengan Kualitas Hidup Pasien Kanker Payudara Di Rsud Prof. Dr. Margono Soekarjo Purwokerto. Jurnal Ilmiah Ilmu-ilmu Kesehatan, $14(2): 16-23$

Farouk O, Zaafarany MIEE (2014). Coping Strategies in Egyptian Ladies with Breast Cancer. Breast Cancer: Basic and Clinical Research 8: 97-102. (2017). Psychosocial Needs Among Indonesian Women Diagnosed With Breast Cancer. Journal of Nursing and $7-72$ 
Hajian S, Mehrabi E, Simbar M, Houshyari $M$ (2017). Coping Strategies and Experiences in Women with a Primary Breast Cancer Diagnosis. Asian Pac J Cancer Prev, 18(1): 215-224

Helalah MA, Al-Hanaqta M, Alshraideh $\mathrm{H}$, Abdulbaqi N, Hijazeen J (2014). Quality of Life and Psychological WellBeing of Breast Cancer Survivors in Jordan. Asian Pac J Cancer Prev, 15(14): 5927-5936

Høyer M, Johansson B, Nordin K, Bergkvist L, Ahlgren J, Lindqvist a L, Lambe M, Lampic C (2011). Health related quality of life among women with breast cancer a population based study. Acta Oncologica, 50: 1015-1026

Hughes S, jaremka LM, Alfano CM, Glaser R, Povoski S P, Lipar AM, Agnese D M, Farrar WB, Yee LD, Carson WE, Malarkey WB, Glaser JKK (2014). Social support predicts inflammation, pain, and depressive symptoms: Longitudinal relationships among breast cancer survivors. Psychoneuroendocrinology, 42: 38-44.

Husni M, Romadoni S, Rukiyati D (2015). Hubungan Dukungan Keluarga Dengan Kualitas Hidup Pasien Kanker Payudara Di Instalasi Rawat Inap Bedah RSUP Dr. Mohammad Hoesin Palembang Tahun 2012. Jurnal Keperawatan Sriwijaya, 2 (2): 77-83

IARC (2017). Estimated age-standardized rates (World) (incidence and mortality). https://gco.iarc.fr/today/onlineanalysis-dual-bars? mode $=$ cancer\&mode_population $=$ continents\&popul ation $=900 \&$ se $x=0 \&$ cancer $=29 \&$ type $=$ o\&statistic $=0 \&$ prevalence $=0 \&$ color $\_p$ alette $=$ default

Irawan E (2013). Pengaruh Perawatan Paliatif Terhadap Pasien Kanker
Stadium Akhir (Literature Review). Jurnal Ilmu Keperawatan 1(1).

Kemenkes (2015). Stop Kanker. Jakarta: Pusdatin.

(2015). Pedoman nasional Program paliatif. Jakarta: Kementerian Kesehatan RI.

(2016). Bulan Peduli Kanker Payudara. Jakarta: Infodatin.

Khalili N, Farajzadegan Z, Mokarian F, Bahrami F (2013). Coping Strategies, Quakity of Life and Pain in Women With Breast Cancer. Iran J Nurs Midwifery res, 18(2): 105-111.

Kroenke CH, Kwan ML, Neugut AI, Ergas IJ, Wright JD, Caan BJ, Hershman D, Kushi LH (2013). Social networks, social support mechanisms, and quality of life after breast cancer diagnosis. Breast Cancer Res Treat, 139(2): 515527.

Kvillemo P, Branstrom R (2014). Coping with Breast Cancer: A Meta-Analysis. PloS ONE 9(11).

Li L, Zhu X, Yang Y, He J, Wang Y, Zhang J (2015). Cognitive emotion regulation: characteristics and effect on quality of life in women with breast cancer. Health and Quality of Life Outcomes, 13(51): 1-10.

Leung J, Pachana NA, Laughlin DM (2014). Social support and health-related quality of life in women with breast cancer: a longitudinal study. PsychoOncology.

Lusiatun, Mudigdo A, Murti B (2016). The Effect of self-Efficacy, Family Support, and Socio-Economic Factors on the Quality of Life of Patients with Breast Cancer at Dr Moewardi Hospital. Journal of Epidemiologi and Public Health, 1 (3): 193-205.

Mardiana D, Ma'rifah AR, Rahmawati AN (2013). Hubungan Mekanisme Koping Dengan Kualitas Hidup Pen- 
derita Kanker Servik Di RSUD Prof. Dr. Margono Soekarjo Purwokerto. Jurnal Keperawatan Maternitas, 1(1): 9-20.

Pinto AC, Azambuja ED (2011). Improving quality of life after breast cancer: Dealing with symptoms. Maturitas 70: $343-348$.

Prastiwi TF (2012). Kualitas Hidup Penderita Kanker. Developmental and Cinical Psychology, 1(1): 21-27.

Rab F, Amardeep TS (2012). Social Support as a determinant of Health Related Quality of Life in Breast Cancer survivors in California Graduate Program in Epidemiology and Biostatistics. Epidemiology Commons Health Services Research Commons. Retrieved from http://ir.lib.uwo.ca/etd.

Rasjidi I (2010). 100 Question \& Answer Kanker Pada Wanita. Jakarta: PT Elex Media Komputindo.

Rudiyo, Nugroho RS, Soediro R, Gondhowiardjo S, Siregar NC, Djoerban Z, Poetiray EDC (2012). Kualitas Hidup Jangka Panjang Pada Pasien Kanker payudara Dengan menggunakan Kuesioner EORTC QLQ C-30 Dan Modul BR-23. Jurnal Radioterapi Dan Onkologi Indonesia, 3 (3): 88-89.

Sastra L (2016). Hubungan Dukungan Keluarga Dengan Konsep Diri Pasien Kanker Payudara. Jurnal Keperawatan Muhammadiyah, 1 (1): 7-12.

Schreiber JA (2011). Image of God: Effect on Coping and Psychospiritual Outcomes in Early Breast Cancer Survivors. Oncology Nursing Forum, 38(3): 293-301.
Silva SM, Crespo C, Canavarro MC (2012). Pathways for psychological adjustment in breast cancer: A longitudinal study on coping strategies and posttraumatic growth. Psychology \& Health, 27(11): 1323-1341.

Siregar AR, Rina NM (2014). Gambaran Kualitas Hidup Pada Wanita Dewasa Awal Penderita Kanker Payudara. Psikologia, 9(3): 82-88.

Sulistiowati E, Lolong DB, Pangaribuan L (2016). Gambaran Penyebab Kematian Karena Kanker Di 15 Kabupaten/ Kota, Indonesia Tahun 2011. Buletin Penelitian Sistem Kesehatan, 19(2): 119-125.

Wang F, Liu J, Wang F, Ma Z, Gao D, Zhang Q, Yu Z (2014). The status and correlates of depresion and anxiety among breast-cancer survivors in Eastern China: a population-sectional case-control study. BMC Public Health 14: 326.

WHO (2017). Breast cancer: prevention and control. http://www.who.int/cancer/detection/breastcancer/en/.

Zucca AC, Boyes AW, Lecathelinais C, Girgis A (2010). Life is precious and I'm making the best of it: coping strategies of long-term cancer survivors. Psycho-Oncology 19: 12681276. 